\title{
KAJIAN SIFAT FISIK DAN KIMIA BUAH STROBERI BERDASARKAN MASA SIMPAN DENGAN PENGOLAHAN CITRA
}

Study of Physical and Chemical Properties of Strawberry Fruit Based on The Self Life with Image Processing

\author{
Rizky Ramadani Dwi Utari ${ }^{1)}$, Dedy Wirawan Soedibyo ${ }^{1) *}$, Dian Purbasari $^{1)}$ \\ ${ }^{1)}$ Jurusan Teknik Pertanian, Fakultas Teknologi Pertanian, Universitas Jember \\ Jl. Kalimantan 37, Kampus Tegal Boto Jember 68121 \\ *E-mail: qqimoutz23@gmail.com, dedy.soedibyo@gmail.com
}

\begin{abstract}
In the storage processes strawberries experiencesdetrimental changes so that they can affect the quality of fruit. This change can be detected by testing the physical and chemical properties in particular shelf life period. In generally the measurement of physical and chemical properties are done manually andcausing damage to the object being observed (destructive method). Based on description above, it is necessary to measure non-destructive method using digital image processing. This study aimed to identify the relationship between physical and chemical propertiesvariables and image quality variables (area, height, widht, perimeter red index andblue index) based on 0, 1, and 2 days shelf life using an image processing program. The sample used in this study were 155 pieces strawberry from A quality. The strawberry image was taken by using a CCD camerathen extracted using SharpDevelop 4.2 software. Physical and chemical properties of the strawberry were measured using digital $O^{\prime}$ hauss pioneer scales, penetrometer, refractometer and $\mathrm{pH}$ meter to obtain data on weight, hardness, total dissolved solids and acidity $(\mathrm{pH})$. Correlation test results indicated from strong to very strong relationship between physical and chemical properties variablesand image quality variables with a range of correlation coefficient values from 0,725 to 1,000. Image quality variables that could be used as input for estimating shelf life was blue index, with validation test resulted $87,7 \%$ total accuracy.
\end{abstract}

Keywords: characteristics, chemical, image processing, physical, shelf life, strawberry

\section{PENDAHULUAN}

Tanaman stroberi merupakan salah satu tanaman buah-buahan yang memiliki nilai ekonomi tinggi. Daya pikatnya terletak pada warna buah yang merah mencolok dengan bentuk yang mungil, menarik serta rasa yang manis segar (Gunawan, 2000).

Menurut Kementerian Pertanian Direktorat Jenderal Hortikultura, produksi stroberi pada tahun 2013 yaitu sebesar 90.352 ton dan pada tahun 2014 produksi stroberi menurun menjadi 58.882 ton. Sedangkan menurut Badan Pusat Statistika, nilai impor stroberi segar ratarata per tahun (dalam 5 tahun terakhir yaitu 2009-2013) mencapai $950.140 \mathrm{~kg}$ dan rata-rata nilai ekspor stroberi segar pertahun mencapai $19.445 \mathrm{~kg}$ (19 ton). Hal ini menunjukkan bahwa minat konsumen terhadap stroberi lokal masih rendah, sehingga diperlukan penanganan pascapanen yang dapat mempertahankan kualitas buah stroberi.

Kualitas stroberi juga dapat dipengaruhi oleh penanganan pada waktu pascapanen yaitu pemetikan dan penyimpanan buah. Menurut Balitjestro (2015), pemetikan yang dilakukan 14 hari setelah berbunga memiliki daya simpan selama 3-4 hari. Jika buah dipetik lebih dari itu, maka akan mengakibatkan buah akan cepat mengerut dan membusuk. Hal ini menunjukkan bahwa semakin lama atau cepat waktu pemetikan buah stroberi akan 
mempengaruhi daya simpan dan kualitas buah tersebut.

Proses penyimpanan buah stroberi akan mengalami perubahan yang sifatnya merugikan sehingga dapat mempengaruhi kualitas mutu buah. Proses perubahan ini bisa dideteksi dengan pengujian sifat fisik dan kimia pada setiap periode umur simpan. Selama ini pengukuran sifat fisik dan kimia dilakukan secara manual sehingga akan menghasilkan mutu yang tidak seragam karena adanya perbedaan presepsi, memiliki tingkat akurasi yang rendah dan dapat merusak objek yang diamati.

Berdasarkan hal tersebut, maka diperlukan adanya pengukuran dengan menggunakan pengolahan citra digital. Pengolahan citra merupakan teknik mengolah gambar dan dapat menghasilkan informasi dari gambar tersebut sehingga dapat digunakan untuk menganalisis gambar tanpa merusak (non destruktif) objek yang diamati dan menilai objek secara kuantitatif (Ahmad, 2005). Melalui metode pengukuran citra digital ini kemudian dilakukan analisis antara variabel mutu citra dengan variabel sifat fisik dan kimia berdasarkan umur simpan.

\section{METODE PENELITIAN}

\section{Alat dan Bahan}

Alat yang digunakan dalam penelitian citra digital dan sifat fisik dan kimia buah stroberi adalah kamera CCD 31BUO4.H, seperangkat meja pengambilan gambar, 4 buah lampu TL, kain putih sebagai background, PC TOSHIBA C640, Software Pengolah Citra Sharp Develop, Software Ms. Excel 2007, lux meter, refraktometer, penetrometer, timbangan digital O'hauss Pioneer dan $\mathrm{pH}$ meter. Bahan penelitian ini menggunakan buah stroberi dengan jumlah sampel sebanyak 155 buah dengan kualitas A. Sampel diperoleh dari Desa Jetak Kecamatan Sukapura Kabupaten Probolinggo.

\section{Tahapan Penelitian}

\section{Pengambilan Citra Buah Stroberi}

Pengambilan citra dilakukan dengan menggunakan kamera CCD digital. Perekaman citra dilakukan dengan menggunakan software IC Capture 2.2 dengan format RGB dan disimpan dalam file bereksistensi bmp. Selanjutnya dilakukan pembuatan program pengolahan citra menggunakan software Sharpdevelop 4.2 yang akan digunakana untuk proses ekstraksi citra. Data hasil ekstraksi disimpan dalam bentuk text.

\section{Rancangan Percobaan}

Penelitian ini menggunakan metode umur simpan 0 hari, 1 hari 2 hari. Pada masing-masing umur simpan kemudian diambil citranya dan dilakukan pengukuran sifat fisik dan kimia. Hasil pengukuran dianalisis dengan menggunakan uji anova, korelasi, boxplot dan regresi guna mendapatkan persamaan logika pendugaan umur simpan serta sifat fisik dan kimia buah stroberi.

\section{Metode Analisis}

Buah stroberi disimpan pada masa simpan 0 hari, 1 hari dan 2 hari. Pada masing-masing umur simpan, buah diambil citranya kemudian di ekstraksi dengan variabel yang dihasilkan meliputi area, tinggi, lebar, perimeter dan indeks warna RGB. Selain itu juga dilakukan pengujian sifat fisik dan kimia. Pengujian sifat fisik meliputi pengukuran berat buah stroberi dan pengukuran tingkat kekerasan buah, sedangkan pengujian sifat kimia buah meliputi pengukuran total padatan terlarut buah dan derajat keasamaan $(\mathrm{pH})$ buah.

a. Pengukuran berat buah (Prasetyani, 2008)

Pengukuran berat dilakukan dengan menggunakan timbangan digital o'hauss yang memiliki nilai ketelitian 0,001 gram. Pengukuran dilakukan sebanyak tiga kali pengulangan kemudian dirata-rata. 
b. Pengukuran tingkat kekerasan buah (Prasteyani, 2008)

Pengukuran tingkat kekerasan buah dilakukan dengan menggunakan alat penetrometer. Pengambilan sampel dilakukan sebanyak 6 kali yaitu tiga titik diatas dan tiga titik ditengah.

c. Pengukuran TPT buah (Prasetyani, 2008)

Pengukuran TPT (total padatan terlarut) dilakukan dengan menggunakan alat refraktometer dengan satuan "derajat brix" ( $\left.{ }^{\mathrm{o}} \mathrm{Brix}\right)$. Pengukuran dilakukan sebanyak tiga kali dan dirata-rata dengan menggunakan sari buah stroberi.

d. Pengukuran $\mathrm{pH}$ buah (Prasetyani, 2008)

Pengukuran derajat keasaman dilakukan dengan menggunakan alat $\mathrm{pH}$ meter. Pengukuran menggunakan $\mathrm{pH}$ meter dilakukan sebanyak 3 kali pengulangan kemudian dirata-rata dengan menggunakan sari buah stroberi.

Data hasil analisis kemudian diuji dengan menggunakan uji anova, korelasi, boxplot dan regresi. Uji anova dilakukan dengan tujuan untuk menguji hubungan antara variabel citra dengan variabel sifat fisik dan kimia dengan umur simpan stroberi yaitu 0, 1 dan 2 hari. Analisis data menggunakan analisis satu arah untuk mengetahui perbedaan nyata rata-rata antar varian lebih dari dua kelompok sampel akibat adanya satu faktor perlakuan. Uji korelasi bertujuan untuk mengetahui tingkat hubungan antara variabel mutu citra dengan pengukuran sifat fisik buah dan kimia stroberi. Analisis boxplot bertujuan untuk mengetahui nilai-nilai batas yang bisa digunakan untuk membedakan rentang nilai variabel mutu citra berdasarkan umur simpan buah stroberi, sehingga dapat dilakukan proses penyusunan kalimat logika untuk penentuan umur simpan. Analisis regresi digunakan sebagai integrasi sifat fisik dan kimia buah stroberi pada program pengolahan citra buah stroberi.

\section{HASIL DAN PEMBAHASAN}

\section{Image Aquisition}

Image aquisition bertujuan untuk mendapatkan kesesuaian hasil gambar citra dengan keaslian bentuk buah stroberi. Berdasarkan hal tersebut diperoleh jarak kamera dengan obyek yaitu $25 \mathrm{~cm}$, jarak antar lampu $30 \mathrm{~cm}$, jarak lampu dengan meja pengambilan gambar $50 \mathrm{cmdan}$ nilai intensitas cahaya lampu sebesar 1983 lux.

\section{Program Pengolahan Citra}

Penelitian ini menggunakan program Sharp Develop 4.2 dengan variabel citra yang digunakan yaitu area, tinggi, lebar, perimeter, indeks warna merah $(r)$, indeks warna hijau $(g)$ dan indeks warna biru $(b)$. Tampilan program pengolahan citra buah stroberi ditunjukkan pada Gambar 1.

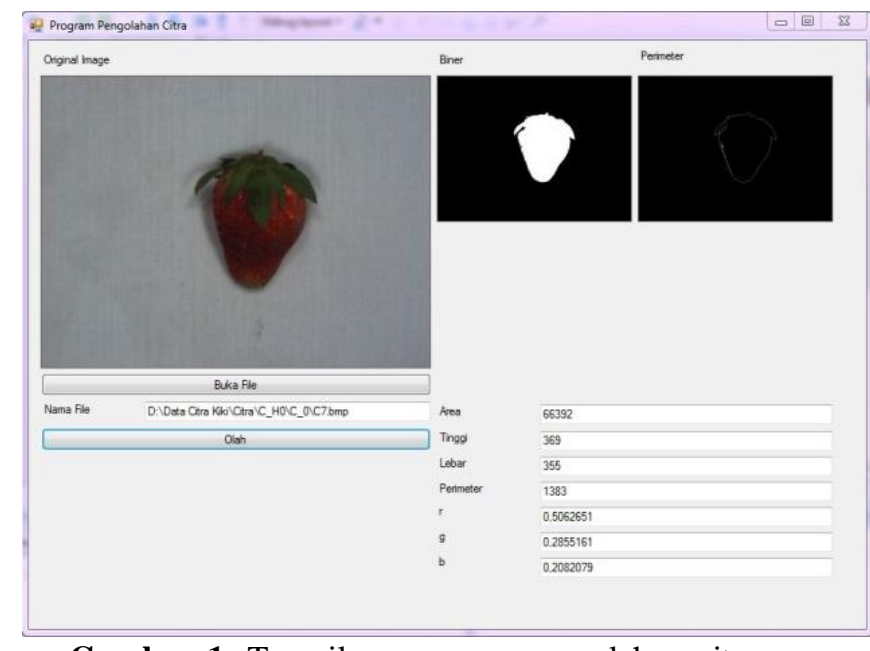

Gambar 1. Tampilan program pengolahan citra buah stroberi

Tampilan prosedur dalam program pengolahan citra terdiri dari komponen perintah, PictureBox dan TextBox. Komponen perintah terdiri atas dua tombol yaitu tombol buka file dan tombol olah. Tombol buka file berfungsi untuk membuka file citra. Setelah file citra berhasil dibuka, maka nama file akan muncul pada TextBoxt "Nama File" dan 
citra asli obyek akan muncul pada PictureBox “Gambar Original". Selajutnya pada tombol olah berfungsi sebagai perintah analisis citra yang hasilnya ditampilkan pada 7 buah TextBox dan 2 PictureBox yang telah disediakan. Data hasil analisis citra akan tersimpan secara otomatis dalam "file text".

\section{Penentuan Nilai Batas Segmentasi}

Penentuan nilai batas segmentasi (treshold) bertujuan untuk memisahkan antara objek dan background. Proses penentuan treshold dilakukan dengan cara mengambil beberapa sampel warna RGB dari citra buah stroberi dan background. Selanjutnya dilakukan analisis sehingga didapatkan nilai batas yang sesuai untuk memisahkan antara objek dengan background.

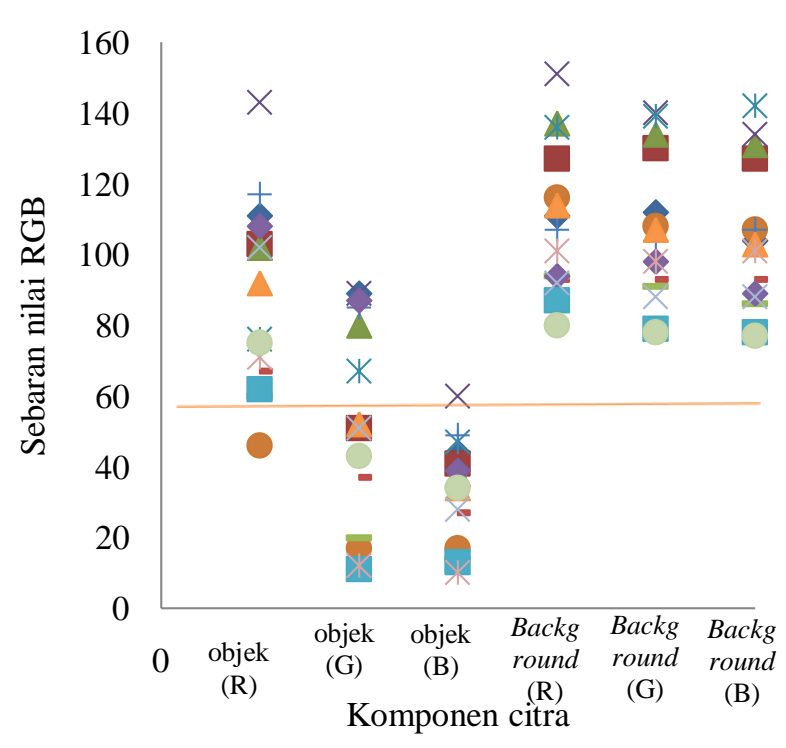

\section{Keterangan:}

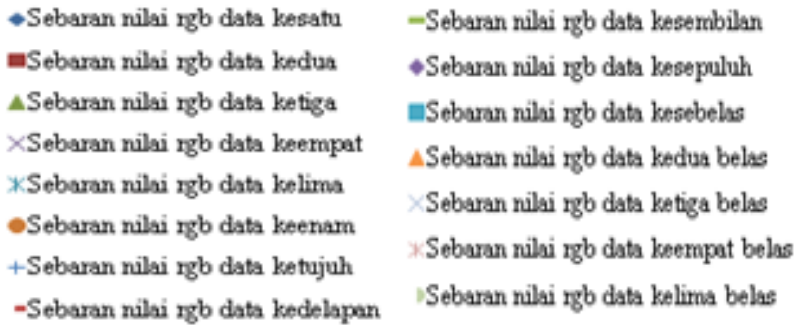

Gambar 2. Sebaran nilai RGB pembentukan objek dan background
Gambar 2 menunjukkan nilai batas segmentasi (treshold). Pada batas segmentasi, nilai sebaran antara $\mathrm{R}$ objek dan $\mathrm{R}$ background bersifat saling tumpang tindih. Nilai sebaran data antara $G$ objek dan $\mathrm{G}$ background juga bersifat tumpang tindih. Namun untuk nilai sebaran data antara B objek dan B background menunjukkan data yang tidak saling tumpang tindih, sehingga dapat digunakan sebagai nilai batas (treshold) dengan mengambil nilai tengah dari keduanya yaitu 68. Berdasarkan hal tersebut maka fungsi treshold dapat diformulasikan dengan rumus: jika $\mathrm{B}>68$ maka akan diidentifikasikan sebagai background dan diubah menjadi hitam (nilai RGB $=0$ ). Selain itu, akan diidentifikasikan sebagai objek dan diubah menjadi putih (nilai RGB = 255).

\section{Ekstraksi Citra}

Ekstraksi citra bertujuan untuk mendapatkan variabel citra. Dalam proses ekstraksi citra terjadi proses tresholding dengan mengubah citra asli menjadi citra biner (Gambar 3). Setelah didapatkan citra biner, kemudian dapat ditentukan nilai dari masing-masing variabel citra. Langkah-langkah yang dilakukan pada proses ekstraksi citra adalah sebagai berikut:

1. Penentuan nilai area buah stroberi dihitung dari jumlah piksel berwarna putih citra biner hasil tresholding.

2. Penentuan nilai tinggi buah stroberi dihitung dari jumlah piksel ordinat atas sampai ordinat bawah area pada citra biner.

3. Penentuan nilai lebar buah stroberi dihitung dari jumlah piksel paling kiri awal citra biner berwarna putih sampai paling kanan akhir citra biner berwarna putih.

4. Penentuan variabel warna ditentukan dari nilai indeks warna RGB pada area buah stroberi. 


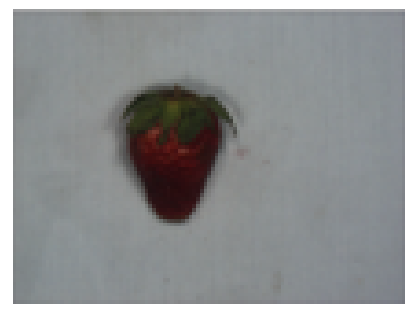

(a)

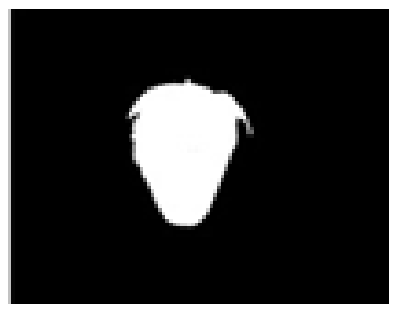

(b)
Gambar 3. Proses thresholding citra: (a) Citra asli; (b) Citra biner

\section{Hasil Pengukuran Variabel Mutu Citra Buah Stroberi}

Hasil pengukuran variabel mutu citra berasal dari data hasil pengolahan citra dalam bentuk text yang diolah menggunakan Ms. Excel. Variabel mutu citra tersebut terdiri atas area, tinggi, lebar, perimeter dan indeks warna RGB. Data hasil pengukuran variabel mutu citra ditunjukkan pada Tabel 1.

Tabel 1. Variabel mutu citra

\begin{tabular}{lccc}
\hline \multirow{2}{*}{ Variabel mutu citra } & \multicolumn{3}{c}{ Umur Simpan } \\
\cline { 2 - 4 } & 0 hari & 1 hari & 2 hari \\
\hline Area (piksel) & 48843 & 36491 & 23675 \\
Tinggi (piksel) & 395 & 360 & 347 \\
Lebar (piksel) & 282 & 279 & 257 \\
Perimeter (piksel) & 1342 & 1194 & 1181 \\
Indeks red & 0.527 & 0.505 & 0.450 \\
Indeks green & 0.270 & 0.274 & 0.303 \\
Indeks blue & 0.203 & 0.221 & 0.247 \\
\hline
\end{tabular}

Data hasil pengukuran pada Tabel 1 menunjukkan bahwa terjadi penurunan nilai rata-rata pada variabel citra area, tinggi, lebar dan perimeter selama masa penyimpanan yang disebabkan oleh adanya proses respirasi. Menurut Supriadi (2015), pada respirasi terjadi pembakaran gula atau substrat yang menghasilkan gas $\mathrm{CO} 2$, air dan energi. Air, gas dan energi yang dihasilkan pada proses respirasi akan mengalami penguapan sehingga buah akan mengalami penyusutan bobot. Penyusutan bobot pada buah stroberi berpengaruh terhadap luas area buah karena pada saat buah mengalami penyusutan. Ukuran buah akan semakin mengecil, sehingga selama masa simpan buah stroberi akan mengalami penurunan nilai mutu area.

Berkurangnya bobot buah juga dapat mengakibatkan buah menjadi layu kemudian kering, sehingga mempengaruhi volume buah yang berdampak pada ukuran (Ratna, 2011). Jika buah stroberi mengalami pengurangan nilai bobot selama masa simpan maka secara otomatis volume buah juga semakin berkurang, sehingga tinggi dan lebar buah stroberi juga semakin kecil. Jika ukuran, volume serta bentuk buah stroberi semakin hari semakin mengecil, maka nilai perimeter buah stroberi yang dihasilkan juga semakin menurun. Hal tersebut dikarenakan perimeter merupakan nilai batas daerah berupa garis antara objek dengan background, sehingga perimeter mengikuti bentuk dari buah stroberi. Perimeter atau tepi biasanya terdapat pada batas antara dua daerah berbeda pada suatu citra (Munir, 2004).

Variabel citra warna RGB mengalami penurunan nilai rata-rata pada indeks red. Hal tersebut disebabkan oleh tingginya konsentrasi anthosianin pada buah stroberi yang membuat warna buah menjadi kehitaman (Supriadi, 2015). Pada indeks warna green dan blue, menunjukkan bahwa terjadi peningkatan nilai rata-rata selama penyimpanan. Hal tersebut kemungkinan dapat disebabkan oleh perbedaan cahaya yang masuk pada objek sehingga membuat perbedaan persepsi warna. Pengambilan gambar buah stroberi dilakukan pada waktu yang berbeda, sehingga menyebabkan adanya sedikit perbedaan cahaya yang masuk pada objek. Menurut Munir (2004), dasar pembentukan persepsi warna adalah digitasi dari warna RGB maka tiga buah filter digunakan untuk mengekstraksi intensitas warna red, green dan blue sehingga bila ketiganya dikombinasikan dapat diperoleh persepsi warna. 


\section{Hasil Pengukuran Variabel Sifat Fisik dan Kimia Buah Stroberi}

Pengukuran sifat fisik dan kimia buah stroberi dilakukan pada masingmasing umur simpan 0 hari, 1 hari dan 2 hari. Data hasil pengukuran sifat fisik dan kimia buah stroberi meliputi pengukuran berat, tingkat kekerasan, total padatan terlarut dan derajat keasamaan $(\mathrm{pH})$ yang ditunjukkan pada Tabel 2.

Tabel 2. Variabel sifat fisikdan kimia

\begin{tabular}{lccc}
\hline \multirow{2}{*}{$\begin{array}{c}\text { Variabel fisik dan } \\
\text { kimia buah stroberi }\end{array}$} & \multicolumn{3}{c}{ Umur Simpan (hari) } \\
\cline { 2 - 4 } & 0 & 1 & 2 \\
\hline Berat buah (gr) & 11,06 & 10,67 & 10,18 \\
Penetrasi & & & \\
(mm/gr.detik) & 0,091 & 0,115 & 0,141 \\
Tpt (brix) & 7,43 & 8,96 & 11,17 \\
pH & 3,31 & 3,36 & 3,51 \\
\hline
\end{tabular}

Berdasarkan Tabel 2 diketahui bahwa selama masa peyimpanan buah stroberi mengalami penurunan pada berat dan peningkatan pada tingkat penetrasi, TPT dan $\mathrm{pH}$ buah. Hal tersebut dapat disebabkan karena selama masa penyimpanan, buah mengalami respirasi yang dapat mengakibatkan perubahan baik secara fisik maupun kimia pada buah.

Menurut Supriadi (2015), penurunan nilai berat buah dapat terjadi karena selama masa penyimpanan buah mengalami respirasi. Hasil dari respirasi tersebut kemudian menguap dan meyebabkan terjadinya penyusutan bobot pada buah. Buah juga mengalami degradasi senyawa pektin dan hemiselulosa yang menyebabkan buah matang menjadi lebih lunak dibandingkan buah mentah.

Perubahan nilai total padatan terlarut disebabkan oleh pemasakan pada buah secara kimia diantaranya yaitu perombakan protopektin (pektin), hemiselulosa dan selulosa oleh enzim pektin metilastrase dan poligalakturonase menjadi senyawa gula sederhana. Selain itu, kematangan buah menyebabkan menurunnya asam organik dan senyawa fenolik yang mengurangi rasa sepat, sehingga menjadi manis yang mengakibatkan $\mathrm{pH}$ pada buah stroberi meningkat (Rahayu et al., 2015).

\section{Analisis Anova Variabel Citra dan Sifat Fisik dan Kimia}

Uji anova dilakukan untuk mengetahui perbedaan nyata nilai rata-rata setiap perlakuan umur simpan 0,1 dan 2 hari dengan menggunakan alfa sebesar 0,05. Hasil perhitungan uji anova ditunjukkan pada Tabel 3.

Tabel 3. Analisis anova pada variabel citra dan variabel sifat fisik dan kimia

\begin{tabular}{lcc}
\hline \multicolumn{1}{c}{ Variabel } & $\begin{array}{c}\text { F } \\
\text { hitung }\end{array}$ & $\begin{array}{c}\text { F } \\
\text { tabel }\end{array}$ \\
\hline Area & 122,08 & 3,028 \\
Tinggi & 18,24 & 3,028 \\
Lebar & 8,80 & 3,028 \\
Perimeter & 17,21 & 3,028 \\
Indeks warna merah & 89,59 & 3,028 \\
Indeks Warna hijau & 39,79 & 3,028 \\
Indeks warna biru & 160,89 & 3,028 \\
Berat buah & 4,60 & 3,36 \\
Total padatanterlarut buah & 319,1 & 3,36 \\
Kekerasan (penetrasi) buah & 6,28 & 3,36 \\
Derajat keasaman buah & 4,24 & 3,36 \\
\hline
\end{tabular}

Semua variabel memiliki pengaruh yang berbeda nyata terhadap umur simpan buah stroberi (Tabel 3). Perlakuan umur simpan terhadap variabel citra, variabel sifat fisik dan kimia menghasilkan perbedaan nilai rata-rata untuk setiap umur simpan 0, 1 dan 2 hari. Menurut Supriadi (2015), terjadinya pengaruh dan perbedaan nilai rata-rata pada variabel citra yang dihasilkan dapat disebabkan karena selama masa penyimpanan buah mengalami perubaha akibat adanya respirasi. Akibatnya, buah mengalami perubahan ukuran atau area dan terjadi perubahan warna. 


\section{Analisis Korelasi pada Variabel Citra dengan Variabel Sifat Fisik dan Kimia Berdasarkan Umur Simpan}

Analisis korelasi dilakukan untuk mengetahui keeratan hubungan antara variabel sifat fisik dan variabel mutu citra. Hasil korelasi antara variabel citra dengan variabel sifat fisik dan kimia buah stroberi dapat dilihat pada Tabel 4.

Tabel 4. Analisis korelasi pada variabel citra dengan variabel sifat fisik dan kimiabuah stroberi

\begin{tabular}{ccccc}
\hline $\mathbf{r}$ & \multicolumn{4}{c}{ Variabel sifat fisik dan kimia } \\
\hline $\begin{array}{c}\text { Variabel } \\
\text { mutu } \\
\text { citra }\end{array}$ & $\begin{array}{c}\text { Berat } \\
\text { buah }\end{array}$ & $\begin{array}{c}\text { Kekerasan } \\
\text { buah }\end{array}$ & $\begin{array}{c}\text { TPT } \\
\text { buah }\end{array}$ & $\begin{array}{c}\mathrm{pH} \\
\text { buah }\end{array}$ \\
\hline Area & 0,999 & $-1,000$ & $-0,996$ & $-0,954$ \\
Tinggi & 0,953 & $-0,966$ & $-0,939$ & $-0,846$ \\
Lebar & 0,929 & $-0,912$ & $-0,945$ & $-0,992$ \\
Perimeter & 0,875 & $-0,896$ & $-0,853$ & $-0,725$ \\
red & 0,983 & $-0,974$ & $-0,99$ & $-0,998$ \\
green & $-0,933$ & 0,916 & 0,948 & 0,994 \\
blue & $-0,999$ & 0,997 & 1,000 & 0,976 \\
\hline
\end{tabular}

Berdasarkan Tabel 4 diketahui bahwa keduanya memiliki hubungan yang sangat kuat antara variabel mutu citra dengan variabel sifat fisik dan kimia buah stroberi, dimana nilai koefisien yang dihasilkan mendekati +1 atau -1 sehingga variabel mutu citra dapat digunakan untuk mengidentifikasi variabel sifat fisik dan kimia buah stroberi.

Menurut Utama dan Antara (2013), buah setelah dipanen masih hidup dan melanjutkan fungsi metabolisme yang dicirikan dengan adanya proses respirasi dan transpirasi sehingga buah mengalami perubahan baik secara fisik maupun kimia. Perubahan tersebut diantaranya yaitu penurunan kadar air yang menyebabkan buah mengalami penyusutan yang berepengaruh pada ukuran buah yaitu area, tinggi, lebar dan perimeter, peningkatan konsentrasi anthosianin pada buah stroberi yang menyebabkan terjadinya perubahan warna yang berpengaruh pada indeks $r g b$, terjadinya degradasi pektin dan hemiselulosa yang mengakibatkan buah menjadi lebih lunak, serta penurunan senyawa asam organik dan terjadinya proses degradasi pati pada buah menjadi gula sederhana yang mengakibatkan cita rasa buah menjadi lebih manis.

\section{Analisis Statistik pada Variabel Mutu Citra Berdasarkan Umur Simpan Buah}

Uji statistik digambarkan dengan analisis boxplot guna mendapatkan nilai batas yang kemudian digunakan untuk penyusunan kalimat logika pendugaan umur simpan buah stroberi. Grafik boxplot variabel mutu citra dapat dilihat pada Gambar 4 dan 5.

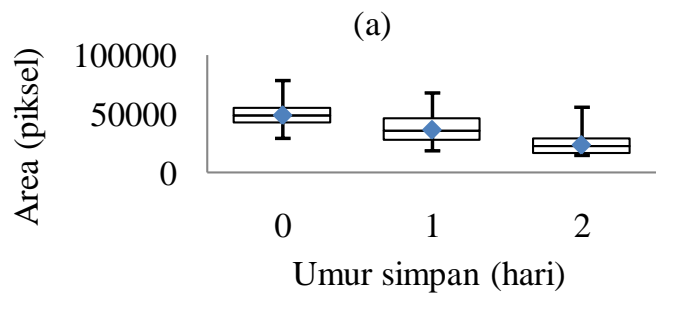

(b)

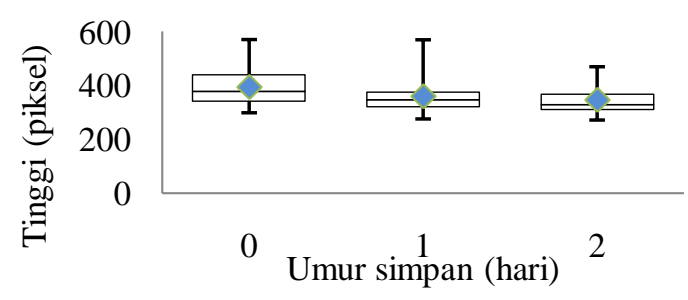

Gambar 4. Grafik boxplot variabel mutu citra buah stroberi yang menunjukkan (a) area; (b) tinggi 
(a)

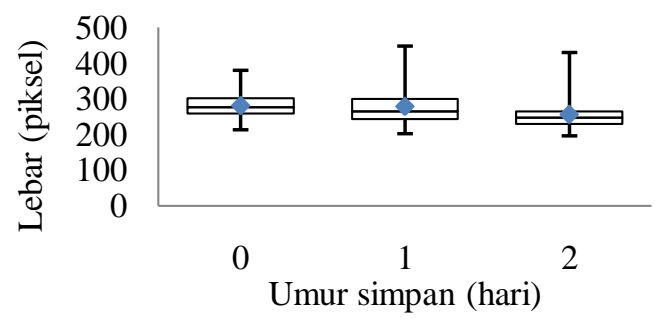

(b)

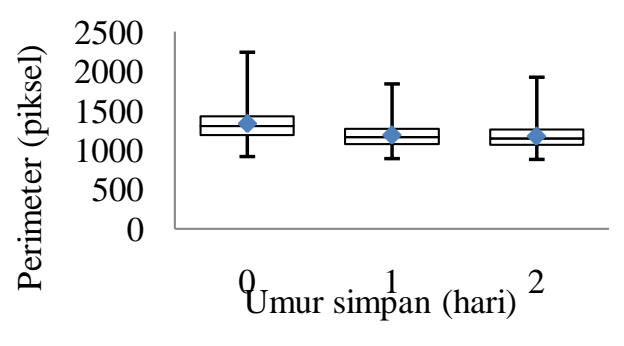

(c)

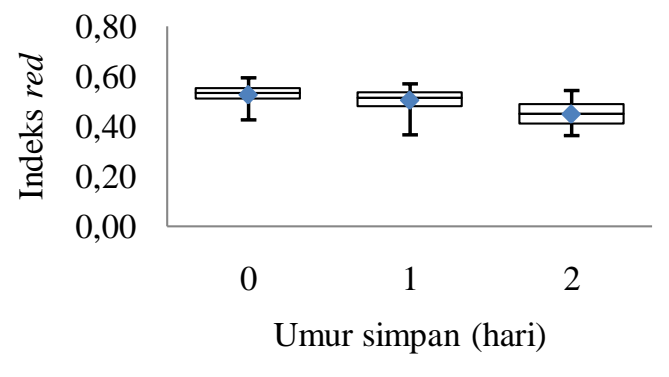

(d)

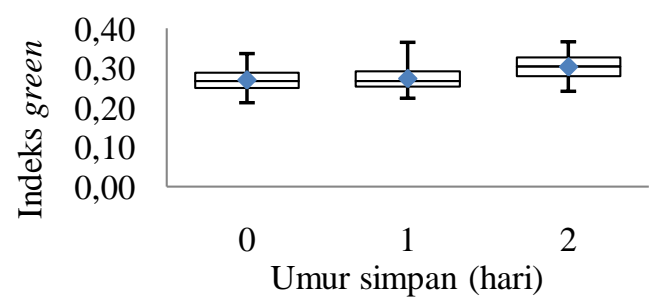

(e)

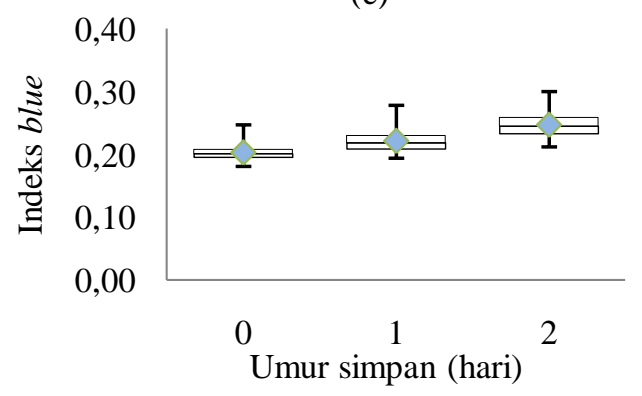

Gambar 5. Grafik boxplot variabel mutu citra buah stroberi yang menunjukkan (a) lebar; (b) perimeter; (c) indeks warna merah; (d) indeks warna hijau; (e) indeks warna biru.
Gambar 4 dan 5 menunjukkan bahwa nilai minimum dan maksimum pada grafik (a), (b), (c), (d), dan (e) pada setiap umur simpan bersifat tumpang tindih sehingga tidak dapat dijadikan sebagai nilai batas dalam penyusunan kalimat logika pendugaan umur simpan buah stroberi. Namun, nilai sebaran data pada grafik (5e) untuk setiap umur simpannya memiliki rentang nilai pada masa umur simpan 0 hari berkisar $0,180-0,247$, pada masa umur simpan 1 hari berkisar $0,193-0,278$ dan pada masa umur simpan 2 hari berkisar 0,211 - 0,300. Hal tersebut menunjukkan bahwa nilai minimum dan maksimum yang dihasilkan pada indeks blue dalam setiap umur simpannya samasama mengalami kenaikan. Oleh karena itu, indeks blue dapat dijadikan sebagai nilai batas dalam penyusunan kalimat logika pada program pendugaan umur simpan buah stroberi. Batas nilai yang digunakan sebagai input validasi program diambil dari nilai tengah atau nilai ratarata antara nilai maksimum pada umur simpan 0 hari dengan nilai minimum pada umur simpan 1 hari serta nilai maksimum pada umur simpan 1 hari dengan nilai minimum pada umur simpan 2 hari.

\section{Penentuan Kalimat Logika Pendugaan Umur Simpan Buah Stroberi}

Hasil analisis statistik dengan menggunakan nilai minimum dan maksimum pada semua variabel citra menunjukkan bahwa terdapat satu variabel yang dapat digunakan untuk memisahkan umur simpan buah stroberi yaitu variabel blue. Dari hasil analisis statistik tersebut didapatkan model persamaan logika pendugaan umur simpan yaitu:

If $($ b_indeks $>=0,180 \quad \& \&<=0,220)$ umur_simpan="0 Hari";

If $($ b_indeks $>0,220 \quad \& \&<=0,245)$ umur_simpan="1 Hari"; If(b_indeks $>0,245 \& \&<=0,300)$ umur_simpan="2 Hari"; 


\section{Integrasi Sifat Fisik dan Kimia Pada Program BerdasarkanUmur Simpan}

Integrasi sifat fisik dan kimia pada progam bertujuan untuk mengetahui nilai sifat fisik dan kimia buah stroberi berdasarkan umur simpan 0,1 dan 2 hari yang ditentukan dari hasil analisis regresi antara sifat fisik dan kimia buah dengan umur simpan buah stroberi. Hasil analisis regresi pada sifat fisik dan kimia buah berdasarkan umur simpan dapat dilihat pada Gambar 6 dan 7.

(a)

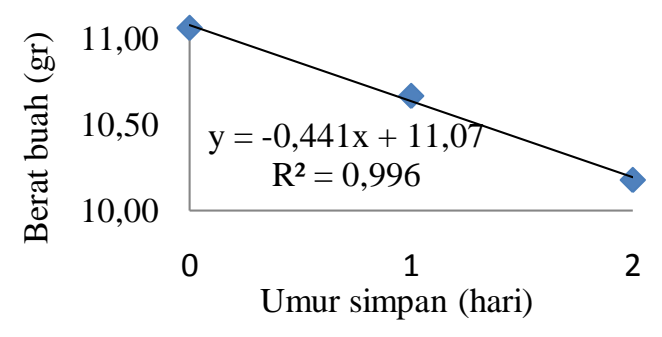

(b)

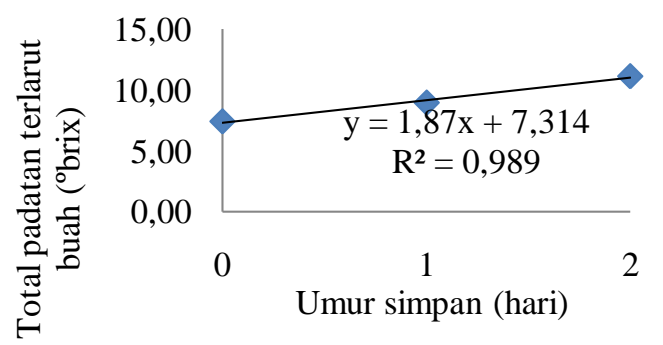

Gambar 6. Analisis regresi linier umur simpan buah stroberi dengan variabel sifat fisik dan kimia: (a) umur simpan dengan berat; (b) umur simpan dengan total padatan terlarut; (a)

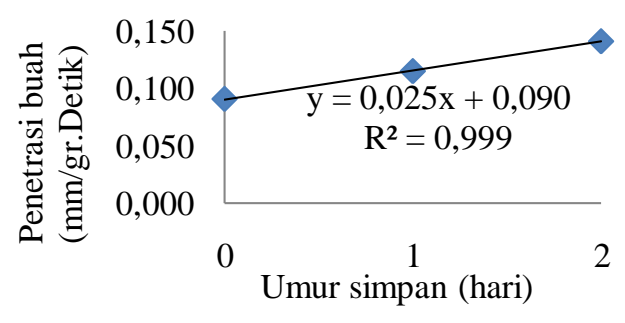

(b)

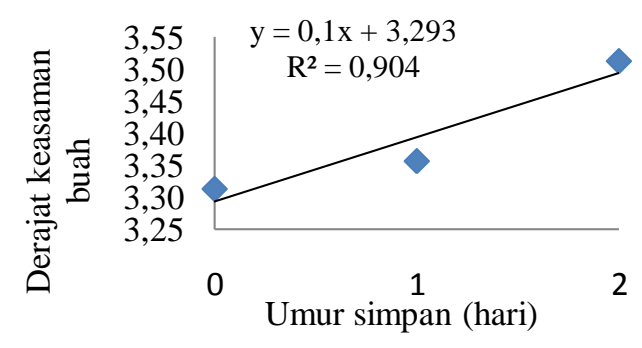

Gambar 7. Analisis regresi linier umur simpan buah stroberi dengan variabel sifat fisik dan kimia: (a) umur simpan dengan kekerasan (penetrasi); (b) umur simpan dengan $\mathrm{pH}$

Gambar 6 dan 7 menunjukkan bahwa nilai koefisien determiasi $\left(\mathrm{R}^{2}\right)$ yang dihasilkan pada masing-masing variabel sifat fisik dan kimia menunjukkan angka yang mendekati 1 dan dapat diinterpretasikan memiliki prediksi yang sangat baik, sehingga dapat digunakan untuk integrasi program pendugaan sifat fisik dan kimia buah stroberi berdasarkan umur simpan. Integrasi program pendugaan sifat fisik dan kimia buah stroberi berdasarkan umur simpan menggunakan nilai y hasil dari persamaan regresi pada masing-masing variabel sifat fisik dan kimia (Tabel 5) . 
Tabel 5. Data hasil perhitungan persamaan regresi variabel sifat fisik dan kimia buah stroberi

\begin{tabular}{lccc}
\hline \multicolumn{1}{c}{$\begin{array}{c}\text { Variabel sifat fisik } \\
\text { dan kimia buah }\end{array}$} & 0 hari & 1 hari & 2 hari \\
\cline { 2 - 4 } & 11.07 & 10.63 & 10.19 \\
\hline $\begin{array}{l}\text { Berat buah (gr) } \\
\begin{array}{l}\text { Penetrasi buah } \\
\text { (mm/gr.detik) }\end{array}\end{array}$ & 0.09 & 0.12 & 0.14 \\
$\begin{array}{l}\text { Total Padatan } \\
\text { Terlarut buah (brix) } \\
\begin{array}{l}\text { Derajat keasaman } \\
\text { (pH) }\end{array}\end{array}$ & 7.31 & 9.18 & 11.05 \\
\hline
\end{tabular}

Nilai hasil persamaan regresi kemudian digunakan sebagai integrasi pada program pendugaan sifat fisik dan kimia buah stroberi sebagai berikut:

if $\left(b \_\right.$indeks $>=0,180 \& \& b \_$indeks $<=0,220$ )

Berat=" 11,07 gram";

if(b_indeks $>0,220 \& \& b$ bindeks $<=0,245) B$ erat=" 10,63 gram";

if(b_indeks $>0,245 \& \& b$ bindeks $<=0,300)$ B erat="10,19 gram";

if $\left(\mathrm{b} \_\right.$indeks $>=0,180 \& \&$ b_indeks $<=0.220$ ) TPT="7,31 brix";

if(b_indeks $>0,220 \& \& b$ bindeks $<=0,245) \mathrm{T}$ $\mathrm{PT}=$ " 9,18 brix";

if(b_indeks $>0,245 \& \& b$ bindeks $<=0,300) \mathrm{T}$

$\mathrm{PT}=$ " 11,05 brix";

if $\left(\mathrm{b} \_\right.$indeks $>=0,180 \& \& b \_$indeks $<=0,220$ )

Kekerasan="0,09mm/gr.s";

if(b_indeks $>0,220 \& \& b \_$indeks $\left.<=0,245\right) \mathrm{K}$ ekerasan="0, $12 \mathrm{~mm} / \mathrm{gr} . \mathrm{s} "$;

if(b_indeks $>0,245 \& \& b$ bindeks $<=0,300) \mathrm{K}$ ekerasan="0,14 mm/gr.s";

if $\left(b \_\right.$indeks $>=0,180 \& \&$

b_indeks $<=0,220) \mathrm{pH}=$ "“3,29";

if $\left(b \_\right.$indeks $>0,220 \& \& b$ _indeks $\left.<=0,245\right) p$

$\mathrm{H}=$ "“3,39";

if (b_indeks $>0,2450 \& \& b$ _indeks $<=0,300)$ p $\mathrm{H}=$ "“3,49";

Berdasarkan kombinasi diatas, maka diperoleh kalimat logika yang kemudian ditransfomasikan dalam program pengolahan citra buah stroberi. Program pengolahan citra buah stroberi memiliki tambahan informasi berat buah, total padatan terlarut buah, kekerasan (penetrasi) buah dan derajat keasaman $(\mathrm{pH})$ buah pada Textbox hasil analisis. Tampilan program ditunjukkan pada Gambar 8.

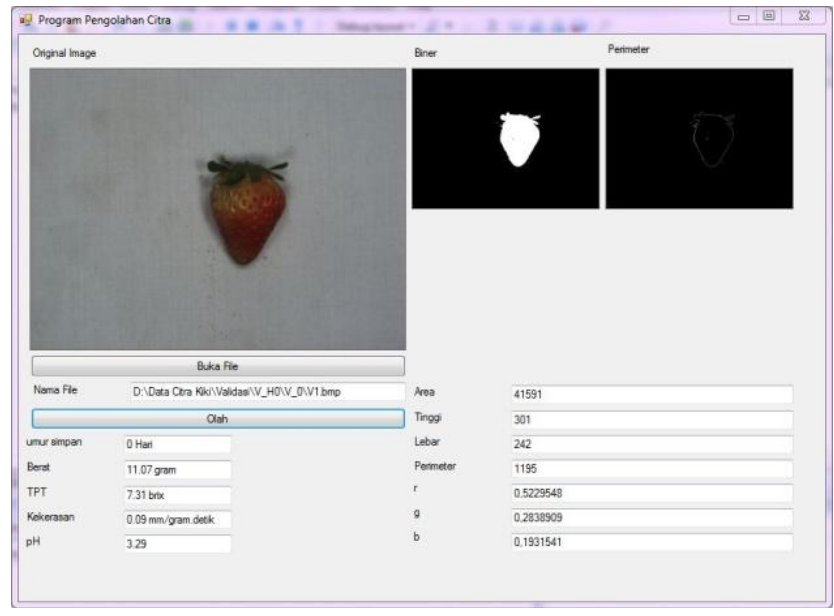

Gambar 8. Tampilan program pendugaan sifat fisik dan kimia berdasarkan umur simpan buah stroberi

\section{Validasi Program Pendugaan Umur Simpan Buah Stroberi}

Validasi program bertujuan untuk mengetahui nilai akurasi program terhadap masing-masing umur simpan. Confussion matrix hasil validasi program dapat dilihat pada Tabel 6.

Tabel 6. Confussion matrix hasil validasi program

\begin{tabular}{|c|c|c|c|c|c|c|c|}
\hline \multirow{2}{*}{\multicolumn{2}{|c|}{$\begin{array}{l}\text { Umur } \\
\text { simpan }\end{array}$}} & \multicolumn{3}{|c|}{ Prediksi } & \multirow{2}{*}{$\begin{array}{l}\text { Total } \\
\text { baris }\end{array}$} & \multirow{2}{*}{$\begin{array}{c}\text { Akurasi } \\
\text { pro- } \\
\text { duksi }\end{array}$} & \multirow{2}{*}{$\begin{array}{l}\text { Kesa- } \\
\text { lahan } \\
\text { omisi }\end{array}$} \\
\hline & & $\begin{array}{c}0 \\
\text { hari }\end{array}$ & $\begin{array}{c}1 \\
\text { hari }\end{array}$ & $\begin{array}{c}2 \\
\text { hari }\end{array}$ & & & \\
\hline \multirow{3}{*}{ Aktual } & $\begin{array}{c}0 \\
\text { hari }\end{array}$ & 10 & 0 & 0 & 10 & $100 \%$ & $0 \%$ \\
\hline & $\begin{array}{c}1 \\
\text { hari }\end{array}$ & 1 & 9 & 0 & 10 & $90 \%$ & $10 \%$ \\
\hline & $\begin{array}{c}2 \\
\text { hari }\end{array}$ & 0 & 3 & 7 & 10 & $70 \%$ & $30 \%$ \\
\hline \multicolumn{2}{|c|}{ Total kolom } & 11 & 12 & 7 & & & \\
\hline \multirow{2}{*}{\multicolumn{2}{|c|}{ Akurasi user }} & 91 & 75 & 100 & & & \\
\hline & & $\%$ & $\%$ & $\%$ & & & \\
\hline \multirow{2}{*}{\multicolumn{2}{|c|}{$\begin{array}{l}\text { Kesalahan } \\
\text { komisi }\end{array}$}} & 9 & 25 & & & & \\
\hline & & $\%$ & $\%$ & $0 \%$ & & & \\
\hline
\end{tabular}

Tabel 6 menunjukkan bahwa program pendugaan umur simpan buah stroberi memiliki akurasi produksi dan akurasi user paling tinggi secara berturut- 
turut terletak pada umur simpan 0 hari dan 2 hari. Akurasi total yang diperoleh adalah $87,7 \%$ yang artinya program pendugaan umur simpan buah stroberi dapat menduga dengan benar hampir seluruh data.

\section{KESIMPULAN}

Variabel citra, variabel sifat fisik dan kimia buah stroberi memiliki hubungan yang kuat hingga sangat kuat sehingga menghasilkan perbedaan nilai rata-rata dan memiliki pengaruh yang berbeda nyata pada setiap umur simpannya. Selain itu program yang digunakan pada pendugaan umur simpan buah stroberi mempunyai akurasi yang cukup besar yaitu $87,7 \%$.

\section{DAFTAR PUSTAKA}

Ahmad, U. 2005. Pengolahan Citra Digital \& Teknik Pemrogramannya. Terbitan Pertama. Graha Ilmu, Yogyakarta.

Badan Pusat Statistika. Tabel impor komoditi. (www.bps.go.id/site/resultTab). [Diakses tanggal 07 Mei 2017].

Balitjestro (Balai Penelitian Tanaman Jeruk dan Buah Subtropika). 2015. Peningkatan kualitas buah segar stoberi melalui penanganan panen dan pascapanen.

(http://balitjestro.litbang.pertanian.go.id/ peningkatan-kualitas-buah-segarstroberi-melalui-penanganan-panendan-pascapanen/). [Diakses tanggal 09 Mei 2017].

Gunawan, L.W. 2000. Stroberi. Penebar Swadaya, Jakarta.

Kementrian Pertanian Direktorat Jenderal Hortikultura. 2015. Statistik produksi hortikultura tahun 2014. (www.google.co.id/search?q=kementria $\mathrm{n}+$ pertanian+direktorat+jenderal+hortik ultura). [Diakses tanggal 15 Mei 2017].

Munir, Rinaldi. 2004. Pengolahan Citra Digital dengan Pendekatan Algoritmik. Informatika, Bandung.
Prasetyani, E. 2008. "Evaluasi Parameter Pemutuan Buah Stroberi (Fragaria chiloensis L.) Menggunakan Pengolahan Citra". Skripsi. Fakultas Tenologi Pertanian IPB, Bogor.

Rahayu, A., Astuti, DP., dan Hamdani, R. 2015. Pertumbuhan dan produksi stroberi (Fragaria vesca L.) pada volume media tanam dan frekuensi pemberian pupuk NPK berbeda. Jurnal Agronida, 1 (1): 46-56.

Ratna N. 2011. Pengaruh Pemeraman pada Pisang Raja (Musa paradisiaca L.) Terhadap Kandungan Gula dan Kadar Air. "Skripsi". IKIP PGRI Semarang, Semarang.

Supriadi, H. 2015. "Pengaruh Penambahan Nanopartikel ZNO dan Kalium Sorbat pada Edible Coating Karagenan dalam Mempertahankan Kesegaran Buah Stroberi (Fragaria sp.) Segar". Skripsi. Fakultas Teknologi Pertanian IPB, Bogor.

Utama, I. M. S dan Antara, N. S. 2013. Pasca Panen Tanaman Tropika: Buah dan Sayur. Modul Kuliah. Universitas Udayana, Denpasar. 